\title{
Book review: Galia Chimiak, The growth of non-governmental development organizations in Poland and their cooperation with Polish Aid, IFiS Publisher, Warsaw 2016, pp. 288
}

\author{
by Katarzyna Zalas-Kamińska
}

Since Poland joined the EU in 2004, the participation of Polish non-government organizations in development aid has become a more popular subject among practitioners, academics and politicians interested in the area of aid. However, this topic in itself wasn't the subject of too many publications. Polish scientists paid their attention to it mainly within the framework of the general debate on Polish development aid (Bagiński, Czaplicka, Szczyciński, 2009; Latoszek, 2010; Kopiński, 2011; Sobotka, 2012). Gathering materials to my doctoral dissertation (title "The Polish non-government organizations - the Ministry of Foreign Affairs cooperation in development aid and public diplomacy"; presented it in 2017), I could see the lack of literature concerning Polish NGOs' participation in development aid as a leading topic. This publication completed, to a certain extent, the publishing market with an important position concerning the participation of Polish non-government organizations in development aid.
For the Polish organizations engaged in development cooperation the author applied the term NGDO (non-governmental development organizations), no matter whether it was an association or a foundation, or - sometimes - a church-related organization. This can be explained by the fact that in the relationship NGO/the state in development aid in Poland, all organizations are included in the regulations and documents regarding development aid. Anyway, it needs to be emphasized that the state (including the MFA) has been officially using the term "non-governmental organizations" (NGOs), which the author also used alternately with NGDOs (as well as with terms 'civil society' and 'third sector'). One has to be aware of another thing: some Polish non-governmental organizations involved in development aid also carried on activities other than developmental. For example the priority tasks of the Stefan Batory Foundation are - apart from the development of international cooperation - improving the quality of Polish democracy and strength- 
ening civil institutions in public life in Poland. And, although the Polish Centre for International Aid actually works in the international arena, the Polish Humanitarian Action (these both NGOs are often compared to each other as the two largest Polish humanitarian organizations) also conducts - very known in Poland - action of feeding Polish children at schools. So, the question is how many of them could really be named NGDOs.

My analysis of the Polish NGOs involved in Polish development aid in between 2004 and 2012, which I conducted in my doctoral thesis, revealed not only a large number of organizations (about three hundred), but also a huge variety. That's why, in my opinion, throwing all organizations into one bag in the research process is a little risky, particularly when we discuss 'social capital', as well as history and an evaluation of the third sector in development aid in Poland especially when we consider that the aim of this book is "to examine the synergistic effect of the cooperation between these two stakeholders".

There are two research questions the author put and tried to unravel. Which factors determined the growth of NGDOs in Poland? What has been NGDOs' role in the evaluation of the Polish aid system? She analyzed the emergence of NGDOs in development cooperation, including personal motivations of Poles involved in this area. Then she researched NGDO's impact on the Polish development aid system, its priorities and modalities; and also she analyzed the relationship between NGDOs and the state (mainly the MFA); she endeavored to demonstrate how Polish aid has been shaped by cooperation between state and non-state actors in development aid.

As the author stated in her Introduction, the object of the research is "the Polish development cooperation system and specifically its non-governmental 'branch"', and the subject "are individuals involved in development cooperation".

To acknowledge her assumptions she completed desk research and interviews with aid professionals, including NGDOs' representatives, policy makers and experts. There were 25 interviews conducted between May 2014 and February 2015 with respondents engaged in development cooperation. Besides that, she took part in conferences on development cooperation and consultation meetings organized at the Polish MFA and the European Commission. From my own experience I know how important and valuable are all of those informal 'off the record' and - sometimes - spontaneous talks with aid professionals, both non-state and state. They are more open and critical in an informal setting (especially when discussing matters on which they should cooperate with each other), which gives the researcher much better analytical perspective. Moreover, the author also analyzed documents, available 
literature (unfortunately limited in quantity and quality) and media releases.

The subject presented in the book required an interdisciplinary research approach. Aware of this, the author refers to international relations, psychology, sociology, political studies, and also to supply-side economic theories of nonprofit organizations. At the same time she emphasis that her research broadly concerns the field of the sociology of development. She assumes a micro perspective (aid professional perspective) and she holds this perspective over the entire book. Similarly, she refers to a constructivist way of thinking, which is the main and pertinent theoretical underpinning of her research. She researched the Polish NGDOs' case in accordance with the second generation of constructivist scholars, who moved the discussion from public international governance towards private international governance,. She binds their activity with "moral authority" and "rational voluntarism" (R.B. Hall and T.J. Biersteker).

The book consists of five chapters. The chapters are answers to a number of supplementary researched questions (besides the two mentioned at the beginning). It prompts the reader to explore and consider. It also shows how difficult it is to research human beings (in this particular case, aid professionals) and how many aspects needed to be included. Each chapter begins with a quotation, which - in most cases - additionally identifies capital - both social and cultural - of Polish NGDOs activists as well as governmental actors. The author cites, for example, the president of Poland Andrzej Duda and Janina Ochojska, president of Polish Humanitarian Action.

In the first chapter she seeks postcommunist determinants and impacts that have shaped the role of civil society organization in development. To find them she emphasizes some modern quandaries, such as those associated with changes in the area of global wealth distribution and in the perception of power. Moreover she presents different attitudes pervading the roles of civil society organizations in international relations, particularly in international development. Considering the triumph or fall of liberalism in the context of civil society, she brings personal motivation for active participation in public life and for bringing "innovation", creating "change" and introducing "new solutions to social problems" as a proof of existence of 'social capital' and its relevance for development (as well as for democratization) and for advocacy "for social change leading to global justice".

One may find her references to the realist and neo-realist perspectives, the "revisionist" school, the "structuralist" school and the "globalists". When mentioning neoliberal thinking, she points it out as the best for explanation to the evolution of social activism in Poland. 
Finally, there are also some theories addressed to the pro-social engagement and to the context of the post-communist transformation presented.

Recalling scientists (J. Boli, G.M. Thomas) who considered internationallyoriented NGOs' activities in the context of "world citizenship" and "global citizenship" she treats citizens as the new global development actors. There is assumed to be solidarity with other nations and societies in tackling global problems and challenges. But what's human motivation about? What makes individuals want to become aid professionals? As one may expect, answering these questions is not easy and unequivocal. So, the author leads the reader through aspects such as: "prosocial motivation" (J. Reykowski), "the concept of reference group” (H. Hyman), "identification theory" (P. Schervish, J. Havens), "microstuctural theory of volunteering and giving" (W.Sokołowski), and finally to "motivation to work" (Ch. Handy), which she claims to be most appropriate to her research. According to this approach,"each individual has a set of needs and of desired results, both of which are mediated by a motivational calculus".

Regarding the context of the postcommunist transformation she writes about three-dimensional transformation, firstly towards democracy, secondly, towards a market economy, and thirdly, a Western-style civil society. She claims that the growth of the final element was triggered by "the collapse of the Soviet Union", as well as by "the efforts of the West to secure its influence in Central and Eastern Europe (CEE)".

All these assumptions she uses then (in the last chapter) to unravel the most typical motivational underpinnings of Polish aid professionals. But already at this stage she refers to Poland. Firstly, she points out that civil society had a primary role in the toppling of the previous regime. So, for international donors who wanted to secure influence in Central and Eastern Europe, direct support for Polish civil society seemed to be a natural course of things. It is not a surprising conclusion then that this foreign support appeared to be "a catalyst in the development of the Polish Third sector". In fact, according to P. Pospieszna, impact of foreign aid on the development of the non-governmental sector in Poland had financial, but also educational, cultural and political dimensions. The most sizeable support the Polish Third sector received was from the United States, so 'American values' were the most influential. But funds flowed also from Great Britain, Germany, France, Sweden and Denmark.

Underlining the fact that the nongovernmental sector in Poland has changed over recent decades, she emphasizes how from recipients of foreign aid they have become aid providers to other countries. Moreover their experience in toppling communism and participation 
in successful democratization, justifies the implementation of Polish aid by Polish NGDOs, especially in the field of democracy assistance. Actually, that's how Polish experience in transition and democratization started being perceived as Poland's comparative advantage ("the spirit of solidarity"). I considered it in one of my articles: "Successful transformation - is it really something that Poland can give as an example to less developed countries?" (Kamińska, 2014); it was also an important part of my conference's presentation at University of South California, where in 2016 I presented the topic: Development aid and public diplomacy as tools of Polish smart power in the context of NGO activity".

In the second chapter the development of the NGDO sector during the transformation of Poland from a recipient of foreign aid to donor is discussed.

Firstly, G. Chimiak draws attention to the role of the social movement associated with the trade union Solidarity in toppling the communist regime as pivotal for development of the NGDO sector. She also writes about Poles whose importance for this support was also significant. She recalls for instance Zbigniew Brzeziński, Irena Grudzińska-Gross and Zbigniew A.Pełczyński.

Secondly, as it was mentioned above, external support (mainly American) to self-organization in Poland was significant. Not only financially, although Poland and
Hungary "received the largest share of foreign foundations' involvement with democracy assistance". As she writes "civil society activists in Poland were exposed to new ideas and approaches via their cooperation with Western partners". She writes about the positive and negative effects of foreign support for the Polish third sector, and she shows how this sector started acting in terms of "projects". She gives examples of the Sarros Foundation's support to East East Beyond Borders programme, administered by the Stefan Batory Foundation. As important at the beginning of the transition she lists also the Charles Steward Mott Foundation, the France Pologne Foundation, the Ford Foundation, the Levi Strauss Foundation and Alfred Jurzykowski Foundation.

Then she analyzes the Polish NGDOs potential for gaining funding from the European Union. Poor performance in the use of EU funding, she claimed, was due to several factors, amongst which limited third sector capacity, lack of support for NGOs in terms of their "own funding" and the end of "golden era" of foreign support are mentioned.

In the background of these considerations one should be aware of some of the current aspects at that time, including law and general trends in the development of the NGOs sector after 1989. That's why the author presents the Constitution of Republic of Poland (1997), the Law on Public Benefit Activity and Volunteerism 
(2003) as well as Association Law (2016). She emphasizes: "all NGOs have been gradually earning their legitimization as important institutional actors on the public sphere". Then she includes data that shows how the third sector in Poland was divided, how many Polish NGOs were registered just after 1989 and how many organizations were really active (not only registered) and how their attitude towards institutionalized civil activism and competing with each other changed. She writes about an interesting trend: Poles prefer to establish a foundation rather than an association, and the reason for that she sees in "progressing individualization of social life". So far, according to data from 2015 , there were 86 thousand associations and 17 thousand foundations in Poland. Only $10 \%$ of them worked internationally, but of course not all in ODA recipient countries. To sum up the data, she writes: "Two and a half decades after the onset of the reforms, it has been argued that Poland is one of the two countries in post-communist Europe and Eurasia in which civil society organizations exhibit the highest level of sustainability".

The third chapter, titled From Solidarity to Global Solidarity, focuses on the history and evolution of the Polish NGOs in development cooperation. The NGOs' evolution from aid recipients to professional aid deliverers in development and humanitarian projects and government's main partner in organizing international volunteering and in global education, is presented.

Analyzing it she refers to previously published divisions. One of them, relating to the period 1989-2002 and presented by K.Stanowski, divided the history of Polish NGOs' engagement in foreign aid into three stages. The first, from 1989 till 1994, was the time when the Polish NGOs learnt from their Western partners and established some foreign neighborhood contacts. The second, from 1995 till 1999, was the time when NGOs started being active in bilateral and trilateral cooperation. After 1999, which was the third stage, there was a "rapid boom" of NGOs activity in development aid. In turn, referring to I. Iłowiecka-Tańska and her division of the international engagement of Polish NGOs after 1989, we should notice three separate stages. One when organizations were financed mainly by foreign funds (public and private, mainly American), the next, when Poland initiated the debate on its cultural diplomacy, and the final one - since Poland joined the EU in 2004. According to the author's point of view, "Perhaps it would be most accurate to say that the several trends related to the internationalization of Polish NGOs activities took place in a parallel fashion". And there is no doubt that Polish NGOs were engaged in development aid before Poland implemented its development aid programme. Although the Polish aid system was officially established when 
Poland joined the European Union in 2004, first official Polish Aid projects were conducted 1998. For comparison, in 1992 J. Ochojska, president of the Polish Humanitarian Action - a very known humanitarian organization in Poland organized her first humanitarian aid to Sarajevo. The Stefan Batory Foundation started its aid projects in Ukraine in the early 90 s. Similarly did, for example, the Centre for Economic and Social Research - CASE. It is also worth noting that there were examples of NGO-state cooperation before 2004; for example the Stefan Batory Foundation and The MFA co-organized the conference titled: NATO, the EU and ECE. NGOs in Polish foreign policy" (1999).

She describes official documents concerning Polish Aid, such as Strategy of Polish Development Cooperation (2003), Multiannual Development Cooperation Programme 2012-2015, Multiannual Development Cooperation Programme 2016-2020 and Support for democracy in Poland's foreign policy. First Report Poland's Democratisation Agenda 2014-2015. She analyzed the documents in terms of thematic and geographic directions of Polish Aid. Generally speaking most Polish aid has been delivered to the Eastern Partnership countries and associated with widely understood democratization.

When examining democratization it is worth noting the author's detailed demonstration of the "developmental" and "democratizing" divisions in the NGDO sector. It has already been the subject of scientific publications (Kaca, 2011), as well as the subject associated with the debate over doubts regarding transfer of experience and know-how in democracy and transformation. Both have still been very controversial in the whole international development, although it is worth considering the author's experience from conducted interviews. According to that, firstly "projects should have both development and democratization elements" and secondly "Polish NGO activists firmly believed in the transferability of Polish experience to those countries". Besides, Polish aid professionals are said to have "intuitive knowledge" and "find synergy" with their partners - they "shared common past" and they are from countries with a "comparable level of socio-economic development".

Apart from those already mentioned divisions within the third development sector, there are also some visions, challenges and problems that connect this sector. The lack of financial stability, the issue of improving NGOs' capacity, the lack of agency of Polish NGDOs, clientelistic and non-inventiveness of the Polish aid system, lack of a set of rules on NGDOs activity and widely understood bureaucracy - are worth noting, also because of the fact that they have been a source of NGOs' frustration. I mentioned that in 2015 in my analysis, prepared on behalf on Grupa Zagranica, entitled "Public funding 
of NGOs working in the field of development cooperation based on selected donor states"(Kamińska, 2015).

Actually, while considering the evaluation of the Polish development cooperation system in the fourth chapter, she writes about Grupa Zagranica, an umbrella organization which was established to "build efficient and competent CSOs sector in Poland", to represent NGDOs' interests and to support them. But after more than ten years of existence, it has "reached its glass ceiling". Anyway, it was similar with some of its members. According to G. Chimiak, "while the MFA enhanced its capacity in the area of development cooperation, the NGDO sector has been argued to decline towards stagnation".

All in all she makes an overview of the NGOs-state cooperation in (bilateral) development aid. "The opinions about the role the NGDO sector played in the emergence of the Polish governmental development assistance programme are divided" - the author writes. Generally speaking, NGOs saw themselves as a natural partner for the MFA and they thought they should have been a part of creating the Polish development aid system. At the same time, the MFA saw development aid as "just" another realm of Polish foreign policy.

Undoubtedly, the first step to institutionalize the dialogue between those actors was taken in 2002, so before the Poland's accession to the EU. Polish NGOs and the representatives of the Polish MFA, including minister of foreign affairs W. Cimoszewicz, took part in a conference "Social diplomacy". Moreover, during this conference the document Partnership in foreign policy - A proposal for co-operation between public authorities and non-governmental organizations, was presented; and the seminal role of NGOs in social diplomacy was praised by W.Cimoszewicz. These 2002 events were described as "a milestone date". Soon after, the Council for Cooperation with NGOs was established.

Also the EU accession brought some institutionalized changes in NGOs-MFA cooperation. Since 2004 Polish nongovernmental organizations have implemented aid projects financed by the MFA. According to my research in between 2004 and 2012 Polish NGOs conducted over eight hundred of such projects. Actually, an in-depth analysis of the NGOs' participation in Polish aid in particular years which after all also shaped both the whole aid system and cooperation between state and non-state actors - is something I miss the most in this book. The more because I conducted this type of analysis myself and I'm aware how important it is to illustrate this type of issue.

Anyway, the author presents the discussion on who was the leader "in the initial cooperation between the MFA and the NGDO sector". As far as I am concerned there are at least two answers to this ques- 
tion. To the NGO sector their leadership is undoubted, and to the MFA its supervision is unquestionable. For sure, if both partners were not engaged in development aid, it would be different itself and the NGOMFA cooperation would be different as well. Moreover, both sides owe each other some contacts and the transfer of human resources. G.Chimiak gives the example of K.Stanowski, as mentioned above. He worked, inter alia, for the Polish third sector (the Foundation for Education - FED), for the Ministry of Foreign Affairs, and currently he's the president of the Solidarity Fund PL, a state treasury foundation engaged in development cooperation.

But she highlighted examples of the difficult art of reaching compromise in NGOMFA cooperation. On the list of NGOs' allegations in relation to government there were: only theoretical consultations on priorities of Polish aid, aid planning based on an annual basis, increasingly challenging procedures for NGOs' project proposals. The MFA refuted these allegations, for example by convincing NGOs to increase their pressure on the Ministry of Finance, which disbursed a budget reserve for development aid.

Moreover Polish NGOs also conducted lobbying and advocacy activities. Then, they were often positioned as being in opposition to the government. For example in NGOs' opinion loans and debt relief shouldn't be included in calculating Polish ODA. They postulate changes in the definition of development aid (it should be changed in accordance with OECDDAC). They insisted on the government to increase - as previously declared - funds for development aid (in 2005 Polish ODA was $0,06 \%$ of GDP, in $2010-0,17 \%$. According to current declaration till 2030 Poland should earmark $0,33 \%$. Most of Polish ODA (about 75\%) is delivered by multilateral channel). Besides they had objections to the list of priority countries.

The author analyzed documents regarding Polish Aid in terms of NGOs participation in this field. NGOs were mentioned in Strategy... from 2003 and their know-how accumulated was appreciated there. Some references to the role of the third sector may also be found in the multiannual plans and in the Act on development cooperation (2012). Besides that, in the framework of the law, the Development Cooperation Policy Council was established, and in this advisory body, Polish NGOs are also represented. Moreover, in 2011 NGOs and the MFA and the Ministry of Education signed Memorandum of Understanding on the Development of Global Education in Poland. They also adopted a set of principles of cooperation between the MFA and social partners. At the same time, the Solidarity Foundation (known up to 2013 as the Polish Know How Foundation for International Development Cooperation) was commissioned to conduct aid activities in the Eastern Partnership and Central Asia countries, as well as in Tunisia and 
Burma, and started re-granting for Polish NGOs in this field. All those elements have influenced the quality of the cooperation.

Apart from activities directly associated with development aid, such as development projects and humanitarian projects, as well as organizing international volunteering and taking part in global education, Polish NGOs have become active in other areas, some of which related to aid policy. For instance Polish public diplomacy, focused, inter alia, on the promotion of democracy as a "Polish specialty" in the world.

In the final chapter she describes the results of her study of aid professionals' career paths and their motivations. The conclusions she presents are very interesting, especially - but not only - because such research hasn't been conducted previously.

She writes that most of the Polish aid professionals interviewed were "brought up in families where at least one parent was a teacher"; they or their parents were involved in Solidarity. Besides they were supported by their families in their choice to work as aid professionals.

Her respondents said that they had believed in "dialogue and community values", besides they referred to similar beliefs regarding "curiosity, responsibility, diligence, interest in politics and participation in public life, openness to diversity, independence, sharing one's talents with others, multitasking".
They feel they are "citizens of the world", who are like a "bridge between the giver and the recipient". For many of them working in development aid is "a calling". They admire John Paul II, Mother Teresa or Ghandi as their role models. They appreciate also, for example, Jacek Kuroń, Adam Michnik, Dalai Lama or Vaclav Havel. When asked about models in development aid, they mention J.Ochojska (the Polish Humanitarian Action) and R.Zduńczyk (the Economic Foundation Poland and East Africa).

The career paths of the aid professionals interviewed were various. Some of them joined the civil sector after working for other development institutions, some of them after working for academic institutions. When asked about their motivation to work in development aid, they declared "intrinsic motivation", self-actualization", "curiosity" and "intention to bring about a change of forwarding an agenda they feel strongly about". As noted by the author they "emerge as social entrepreneurs who are willing to share their vision with others"; to her they have "egalitarian nature", they respect their partners, are into "expanding their knowledge and honing their skills", and finally - they admit it's all a win-win situation.

Although being an aid professional was described by respondents as "rather hard work", they can see some positive "side-effects" of their work: "the positive change of attitudes towards development 
cooperation in society" and "the process of brand recognition of Polish NGDOs and Polish aid". So, which is also positive, they still "opt for staying in the NGDO sector".

Actually, in the book one can find many quotations from aid professionals, especially in the fourth and fifth chapters. This is the main value of this book, because it allows the reader to get closer to the respondents and to know their ways of expressing their thoughts.

In conclusion she focuses on challenges and opportunities. She returns to previously described weaknesses of Polish aid and obstacles that NGDOs need to overcome. And she adds other missing links: insufficient activity of Polish thin-thanks and lack of strong political championship, both to discuss and promote development aid.

However there are - and there will be - differences between non-state and state actors in the perception of development aid, they agree that debate on development aid and raising public awareness in this area are desirable. To achieve that, they have to strive for more and better cooperation. Then such cooperation may perfectly correspond with Polish comparative advantages associated with the promotion and support for the develop- ment of democracy and civil society, and maybe even become an element of Polish specialite de la maison.

\section{BIBLIOGRAPHY:}

Bagiński, P., Czaplicka, K., Szczyciński, J. (eds.). (2009). Międzynarodowa wspótpraca na rzecz rozwoju, Wrocław/Warszawa: Polskie Wydawnictwo Ekonomiczne.

Kaca, E. (2011). Pomoc demokratyzacyjna w polskiej wspólpracy rozwojowej, Warszawa: Instytut Spraw Publicznych.

Kopiński, D. (2011). Pomoc rozwojowa. Teoria i polityka, Warszawa: Difin.

Latoszek, E. (ed.). (2010). Pomoc rozwojowa dla krajów rozwijajacych się na przełomie XX $i$ XXI wieku, Warszawa: Szkoła Główna Handlowa w Warszawie.

Sobotka, B. (2012). Tworzenie polskiego systemu pomocy rozwojowej, Warszawa: Wydawnictweo $\mathrm{CeDeWu}$.

Zalas-Kamińska, K. (2014). Successful transformation - is it really something that Poland can give as an example to less developed countries? In: Development and Democracy. Development Ecosystems in V4: the New Role for Civil Society Organisations and Business Beyond 2015. International Conference Booklet. Bratislava: Pontis Foundation.

Zalas-Kamińska, K. (2015). Public funding of NGOs working in the field of development cooperation based on selected donor states, Wrocław/ Warszawa: Grupa Zagranica 2015. 